\title{
A MICROSCOPY AND MOLECULAR STUDIES OF NOSEMA CERANAE INFECTION IN MAZANDARAN PROVINCE OF IRAN
}

\author{
Nosema ceranae Enfeksiyonunun İran, Mazandaran İlinde Mikroskopik ve Moleküler \\ Çalışması
}

Ali SHIRZADI ${ }^{1}$, Gholamreza RAZMI*

${ }^{1}$ Faculty of Veterinary Medicine, Ferdowsi University of Mashhad, IRAN, ORCID No: 0000-000203803-3727

${ }^{2}$ Department of pathobiology, Faculty of Veterinary Medicine, Ferdowsi University of Mashhad, IRAN, ORCID No: 00000002-0754-1278, Yazışma Yazarı/Corresponding author E-mail: razmi@um.ac.ir

\begin{abstract}
Nosema ceranae as a fungal parasite has been reported from the Apis mellifera in all continents. It causes reduced longevity, depopulation, decreased production, and colony losses in honeybee colonies. This study aimed to determine the prevalence of $\mathbf{N}$.ceranae in the apiaries of Mazandaran province. In this study, we randomly selected $\mathbf{3 2 0}$ hives from thirty-two apiaries and collected twenty old honeybees from the apiaries. The collected samples were examined by microscopy and molecular methods. The results of the microscopic examinations showed that $78.12 \%$ of apiaries were infected with Nosema spp. In addition, $\boldsymbol{N}$. ceranae was identified $84.37 \%$ of apiaries by PCR, while no samples were infected by $\boldsymbol{N}$. apis. Blast analysis of the sequenced samples confirmed the presence of $\boldsymbol{N}$. ceranae infection in the apiaries. Based on the obtained results, a high frequency of $N$.ceranae was detected in apiaries in Mazandaran province.
\end{abstract}

Keywords: Nosema ceranae, Honeybee, PCR, Iran

\section{Öz}

Nosema ceranae, tüm kıtalarda Apis mellifera'dan mantar paraziti olarak rapor edilmiştir. Bal arısı kolonilerinde yaşam süresinin azalmasına, nüfus azalmasına, üretimin azalmasına ve koloni kayıplarına neden olur. Bu çalışmada Mazandaran ili arılıklarında N.ceranae yaygınlığının belirlenmesi amaçlanmıştır. Bu çalışmada, otuz iki arılıktan rastgele 320 kovan seçtik ve arılıklardan yirmi yaşı bal arısı topladık. Toplanan örnekler mikroskop ve moleküler yöntemlerle incelendi. Mikroskobik incelemelerde arılıkların \%78,12'sinin Nosema spp belirlendi. Ayrıca N. ceranae, PCR ile \%84.37'sinde tespit edilirken, hiçbir numune $\boldsymbol{N}$. apis ile enfekte olmamıştır. Sıralı örneklerin gen hizalama analizi sonucunda arılıklarda $N$. ceranae enfeksiyonunun varlığı doğrulandı. Elde edilen sonuçlara göre Mazandaran ilindeki arılıklarda yüksek oranda N.ceranae tespit edilmiştir.

Anahtar Kelimeler: Nosema ceranae, Bal arısı, PCR, İran

\section{GENIŞLETILMIŞ ÖZET}

Amaç: Çalışmanın amacı, Mazandaran ili arılıklarında N.ceranae yaygınlığının mikroskopik ve moleküler yöntemlerle belirlenmesidir.
Gereç ve yöntem: Bu çalışmada, otuz iki arılıktan rastgele 320 kovan seçilmiştir. Her bir kovanda, her bir kovanın çevre çerçevelerinden 20 yaşlı işçi arı toplanmıştır. Bal arılarının karınları normal tuzlu su 


\section{ARAŞTIRMA MAKALESI / RESEARCH ARTICLE}

çözeltisinde öğütüldü. Süspansiyon süzüldü ve santrifüjlendi. Süpernatantlar çıkarıldı ve Pelletler doymuş salin solüsyonu ile karıştıııldı. Birkaç mililitre süpernatan alındı ve solüsyonun geri kalanı atılı. Süpernatanlar, tekrarlanan santrifüjleme yoluyla damıtımış su ile yıkandı. Nihai pelet, Nosema sporunu tanımlamak için mikroskobik olarak incelendi. Bal arılarının geri kalan karın içeriği DNA ekstraksiyonu için kullanıldı. Her numunede Nosema türlerinin saptanması için bir multipleks PCR tahlili kullanıldı. En güçlü banda sahip beş pozitif amplikon da gen dizilimi için seçildi.

Bulgular: Mikroskobik incelemelerin sonucunda arılıkların \%78.12'sinin Nosema spp. belirlendi. Ek olarak, N. ceranae, PCR ile arılıkların \%84.37'sinde tespit edilirken, hiçbir örneğe $N$. apis bulaşmamıştır. Mikroskobik ve moleküler yöntemler arasında adil bir sonuç elde edildi. Ayrıca, fumagillin reçete edilmesinin arılık boyutunda, arılıklarda Nosema spp enfeksiyon oranı üzerinde anlamlı bir etkisi olmamıştır. Sıralı örneklerin gen sıralama analizi, arılıklarda $N$. ceranae enfeksiyonunun varlığını doğruladı.

Tartışma ve sonuç: Birçok çalışmanın sonuçları, $N$. ceranae enfeksiyonunun dünya çapında bir dağılıma sahip olduğunu göstermiştir (Klee ve ark. 2007). N. ceranae yaygınlığı Türkiye'de \%15-100 (Ivgin Tunca ve ark. 2016), Italya'da \%63 (Papini ve ark. 2017), Polonya'da \%80,6 (Michalczyk ve ark. 2011), \%9597 Macaristan'da (Csáki ve diğerleri 2015), Bulgaristan'da \%77 (Shumkova ve diğerleri 2018), Kanada'da \%41-91 (Emsen ve diğerleri 2016) ve Suudi Arabistan'da \%56 (Ansari ve diğerleri 2017).

$\mathrm{Bu}$ çalışmada, mikroskopik ve PCR sonuçları arasında adil bir uyum gözlemlenirken, diğer çalışmalar iki yöntem arasında önemli bir uyum olduğunu bildirmiştir (Khezri ve diğerleri 2018, Papini ve diğerleri 2017). Bal arılarında Nosema enfeksiyonunun tanımlanması ve ayrımı için PCR yönteminin duyarlıığı ve özgüllüğünün ışık mikroskobundan daha yüksek olduğu açıktır (Michalczyk ve ark. 2011). Bununla birlikte, sporlar gözlemlenmesine rağmen, iki örnekte PCR sonuçları negatifti. Sonuçlar, eksik DNA ekstraksiyonu veya esnek duvarların DNA ekstraksiyonu üzerindeki önleyici etkisi ile ilgili olabilir (Webster ve ark. 2004). Bu çalışmada izole edilen $N$. ceranae dizileri, Çin'de toplanan ve GenBank veri tabanında depolanan $N$. ceranae dizileriyle yüksek düzeyde homolojiye sahiptir.
Moleküler inceleme, bu çalışmada arılıklarının $\% 87,37$ 'sinin yalnızca $N$. ceranae ile enfekte olduğunu göstermiştir. Sonuçlarımız, İran arı kovanlarında $N$. ceranae'nin tek nosemosis etkeni olduğunu belirleyen diğer moleküler çalışmalarla uyumludur (Nabian ve ark. 2011, Khezri ve ark. 2018, Mohhamadian ve ark. 2018). Bu çalışmada N. ceranae'nin yüksek oranda yaygınlığı, bölgelerdeki subtropikal iklim ile ilgili olabilir. $N$. ceranae enfeksiyonlarının oranı, diğer bölgelere kıyasla ılıman iklimlerde daha baskın görünmektedir, oysa $N$. apis şu anda daha soğuk iklimlerde daha yaygın olabilir (Fries 2010).

Elde edilen sonuçlara göre İran'ın Mazandaran eyaletindeki arılıklarda yüksek oranda N.ceranae tespit edilmiştir. Ayrıca, fumagillin kullanımı, enfekte olmuş kolonilerde nosemayı kontrol etmek için yeterli değildir.

\section{INTRODUCTION}

Nosemosis is a significant disease in honey bees around the world (Bailey and Ball 1981). Nosemosis is caused by unicellular fungi belonging to class Microsporidia (OIE 2019). Recent molecular research of the SSU rRNA gene was shown a new definition of the Nosema -Vairimorpha clade. Although Nosema species are genetically close to Vairimorpha, but their morphological and developmental features of two groups are very similar. However the taxonomy of Nosema species is not yet well established (Tokarev et al. 2020). Nosema spores are found in feces and are ingested, directly or indirectly, by adult bees. A higher rate of Nosema infection is observed in worker bees compared to drones and queens, probably due to the cleaning activities of worker bees in the hive (Bailey and Ball 1981). The spores then develop in the epithelial cells in the bees' midgut and affect their digestive functions. The spores are expelled in the feces and are able to maintain their infectivity for a long time in cold and heat conditions for several years (Fenoy et al. 2009). The causative agents of nosemosis are $N$. apis and $N$. ceranae that infect Apis mellifera, with different frequency depending on the area (Fries 2010). Nosema apis is distributed especially in cold and temperate regions. It more common during spring and winter. Nosema ceranae is a new species of microsporidium isolated for the first time from Apis cerana, a bee species widespread in Southeast Asia (Fries et al. 1996). The natural infection of Apis mellifera with $N$. 


\section{ARAŞTIRMA MAKALESI / RESEARCH ARTICLE}

ceranae was reported in Spanish apiaries (Higes et al. 2006). The clinical signs of $N$. ceranae infection in adult honeybees are different from $N$. apis. The most prominent symptom in $N$. apis infection is dysentery, while intestinal disorders are not observed in $N$. ceranae infection. The affected honeybees tend to die away from the hive, resulting in progressive depopulation of the colonies (OIE 2019, Fries 2010).

The microscopic spores of $N$. apis are barely morphologically distinguishable from those of $N$. ceranae. It is only possible to make an accurate diagnosis through PCR (OIE 2019). Epidemiological studies have indicated a high prevalence of Nosema spp. in honeybee colonies in the northern half of Iran (Lotfi et al. 2009, Tavassoli et al. 2009, Razmaraii and Karimi 2010, Moshverinia et al. 2012). However, molecular studies have shown only $N$. ceranae infection in the apiaries in different provinces of Iran (Nabian et al. 2011, Khezri et al. 2018, Mohhamadian et al. 2018).

Mazandaran province is located in the Caspian climate, and with abundant flowering plants, it is one of the essential centers of beekeeping in Iran. Nosema ceranae infection was reported the first time from Iranian apiaries in this province (Nabian et al. 2011). This study aimed to determine the prevalence of Nosema ceranae in the apiaries of Mazandaran province by microscopy and molecular assays.

\section{MATERIALS AND METHODS}

\section{Study area}

Mazandaran province is located between the Caspian Sea and Alborz Mountain, extending from latitude $35^{\circ} 45^{\prime}$ to $37^{\circ} 10^{\prime}$ and longitude $50^{\circ} 15^{\prime}$ to $54^{\circ}$ (Fig.1). The Alborz Mountains separate the Mazandaran province from the plateau and prevent Caspian's humidity from extending over the country, and also cause high annual precipitation consisting of snow in the highlands and rain in the lowlands. The abundant precipitation provides suitable conditions for natural vegetative growth in the province (Kazembeyki 2003).

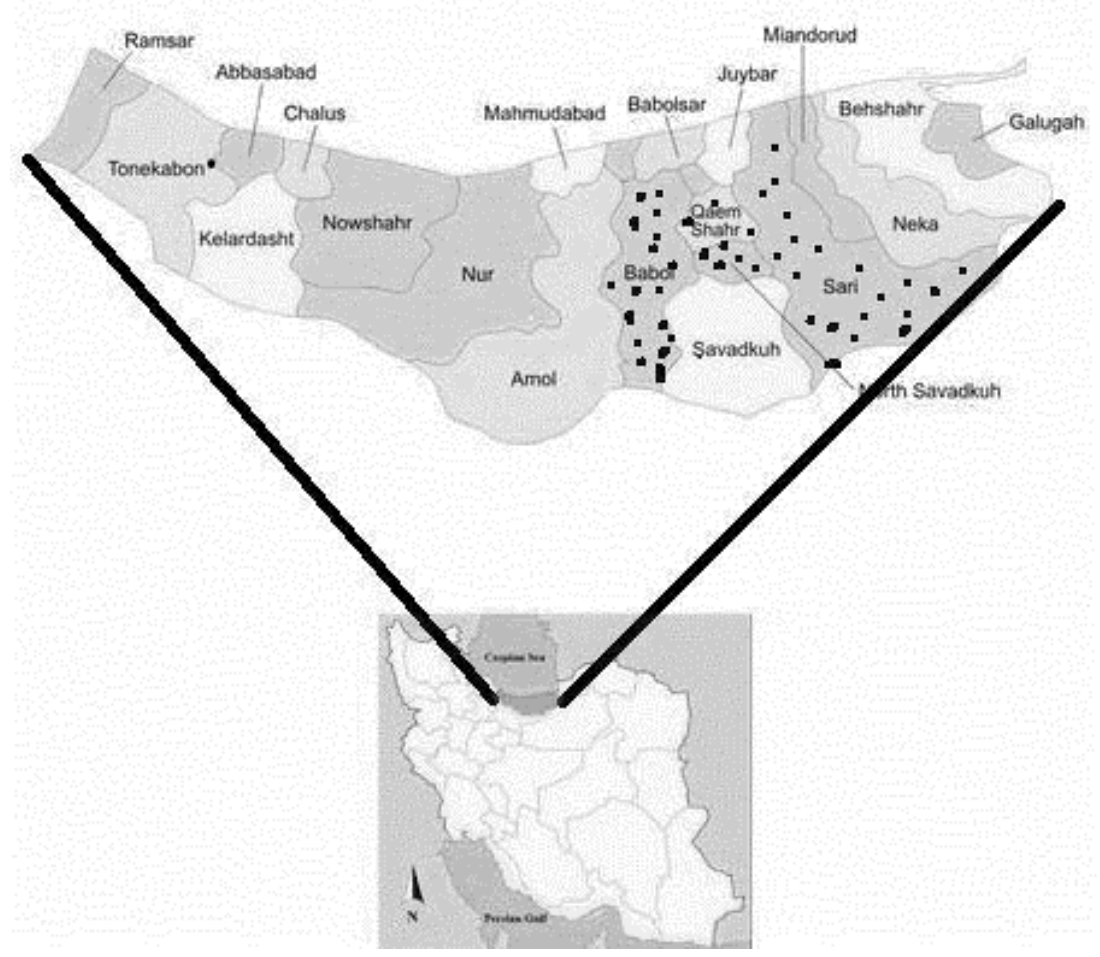

Figure 1. Map of sample collection in the Mazandran Province, Iran. 


\section{ARAŞTIRMA MAKALESI / RESEARCH ARTICLE}

\section{Samples collection}

We collected samples from 320 hives. The sample size was calculated using a $95 \%$ confidence level with $5 \%$ desired absolute precision (Thursfield 1986), based on the prevalence of Nosema spp. infection (59\%) that was previously reported in Azerbaijan province (Razmaraii and Karimi 2010). Thirty-two apiaries were randomly selected and sampled from April to March 2017 in Mazandaran province. The apiaries were located in the Sari, Ghaemshar, Babol and Savadkooh areas (Fig. 1).

After visiting the determined apiaries, the data for each apiary, we obtained from the beekeeper the apiary address, the name of the owner, bee population. Then, the samples were collected from 10 seemingly healthy hives in each apiary, consisting of 20 old worker bees from peripheral frames of each hive (200 honeybees in each apiary) (OIE 2019). The collected bees were put in storage containers and transported immediately to the laboratory under cold conditions.

Samples preparation Twenty honeybees' abdomens from each hive were ground up in $5 \mathrm{ml}$ of normal saline solution. The suspensions were filtered through two layers of muslin to remove coarse bee parts and then centrifuged at $2500 \mathrm{~g}$ for $5 \mathrm{~min}$. and the supernatants removed. Pellets of isolated spores were mixed with saturated saline solution and again centrifuged at $2500 \mathrm{~g}$ for $5 \mathrm{~min}$. Some milliliters of supernatants were taken and the rest of the solution was discarded. The supernatants were washed three times with distilled water and each time they were centrifuged at $2500 \mathrm{~g}$ for $3 \mathrm{~min}$ and the upper parts were discarded. The finel pellets were resuspended in $1.5 \mathrm{ml}$ of distilled water. The final pellets were One drop of the sample was put on a slide and covered with a slip and examined by a light microscope at $\times 400$ magnification. The rest of the homogenate was transferred to an Eppendorf tube at kept at $-20^{\circ} \mathrm{C}$ until use.

\section{DNA extraction and Duplex- PCR}

Total genomic DNA of homogenate samples was extracted according to the protocol of a DNA isolation kit (Molecular Biological System Transfer (MBST), Tehran, Iran). A Multiplex PCR method was used to simultaneous detection of two Nosema species in isolate DNA. (Martín-Hernández et al. 2007). Briefly, in amplification of Duplex-PCR four oligonucleotide PCR primers, 5'GGCGACGATGTGATATGAAAATATTAA-3' as $N$. ceranae forward, 5'CCCGGTCATTCTCAAACAAAAAACCG-3' as $N$. ceranae reverse, and 5''GGGGGCATGTCTTTGACGTACTATGTA-3' as $N$. apis forward and GGGGGGCGTTTAAAATGTGAAACAACTATG -3' as $N$. apis reverse were used Amplification was conducted in $25 \mu \mathrm{l}$ reaction volumes (Accupower PCR premix kit, Bioneer $®$, South Korea) with a final concentration of each dNTP of $250 \mu \mathrm{M}$ in $10 \mathrm{mM}$ Tris- $\mathrm{HCl} \mathrm{pH} \mathrm{9.0,30} \mathrm{mM} \mathrm{KCl} \mathrm{and} 1.5 \mathrm{mM} \mathrm{MgCl}_{2}, 1 \mathrm{U}$ Taq DNA polymerase and 10 pmol of each PCR primer (Takapouzist Co. Iran), Then $1 \mu$ of DNA template was added to each reaction. The remaining $25 \mu \mathrm{l}$ reaction volume was filled with nuclease-free distilled water. The thermocycler program consisted of $94^{\circ} \mathrm{C}$ for $2 \mathrm{~min}$, followed by 10 cycles of $15 \mathrm{~s}$ at $94^{\circ} \mathrm{C}, 30 \mathrm{~s}$ at $61.8^{\circ} \mathrm{C}$, and $45 \mathrm{~s}$ at $72^{\circ} \mathrm{C}, 20$ cycles of $15 \mathrm{~s}$ at $94^{\circ} \mathrm{C}, 30 \mathrm{~s}$ at $61.8^{\circ} \mathrm{C}$, and $50 \mathrm{~s}$ at $72^{\circ} \mathrm{C}$ plus an additional $5 \mathrm{~s}$ of elongation for each successive cycle, and a final extension step at $72^{\circ} \mathrm{C}$ for $7 \mathrm{~min}$. The PCR products were electrophoresed in a $2 \%$ agarose gel with TBE buffer and visualized using ethidium bromide and UVeliminator. A visible band at 321 bp for $N$. apis and $218 \mathrm{bp}$ for $N$. ceranae was produced in the PCR. The positive controls were prepared from the infected honeybees in the last study (Moshverinia et al. 2012) and the nuclease free distilled water as a negative control for each PCR amplification.

\section{Gene sequencing}

Five positive amplicons with the strongest band were selected, purified and sent to gene sequencing (Bioneer Inc, Seoul, Korea). The primers which were previously used for the PCR product of $N$. ceranae were applied for the sequencing reactions. Assembling and editing of sequenced nucleotides was performed using CLC software (CLC Main Workbench, Version5.5).

\section{Statistics analysis}

The relationship between Nosema infection rate and different variables such as the size of apiary and use and non-use of fumagillin was analyzed by the Chisquare test. A significant association was identified when a $p$-value of less than 0.05 was observed. The agreement between the molecular and microscopic tests was showed as a Kappa- coefficient. The agreement as poor if Kappa- coefficient between 0.2 and 0.4, moderate if between 0.4 and 0.6, substantial if 0.6 and 0.8 and good if it exceeds 0.8 and 1, (Petrie and Watson 2006). 


\section{ARAŞTIRMA MAKALESI / RESEARCH ARTICLE}

\section{RESULTS}

In this study, Nosema spp. infection was detected in $78.12 \%$ of apiaries (25/32) by microscopy method (Fig. 2) and $84.37 \%$ of apiaries (27/32) by PCR. $N$. ceranae was the only species of Nosema identified. (Fig. 3). A poor agreement was observed between the microscopy and PCR methods (Table.1). $(\mathrm{Kappa}=0.389)$. No significant statistical differences were identified between the prevalence of $N$. ceranae infection in apiaries by population and the use of fumagillin (Table. 2) ( $p>0.05)$. A blast search against GenBank revealed the highest similarity (100\%) with $N$. ceranae 16SrRNA partial sequence from China (Sequence ID: MF099642.1).

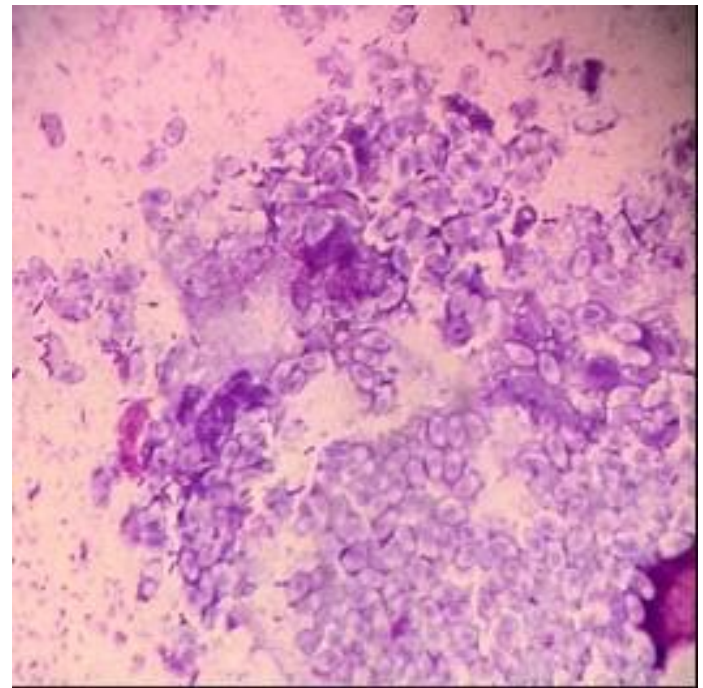

Figure2. Nosema spores stained by Giemsa under a light microscope $(1000 \times)$.

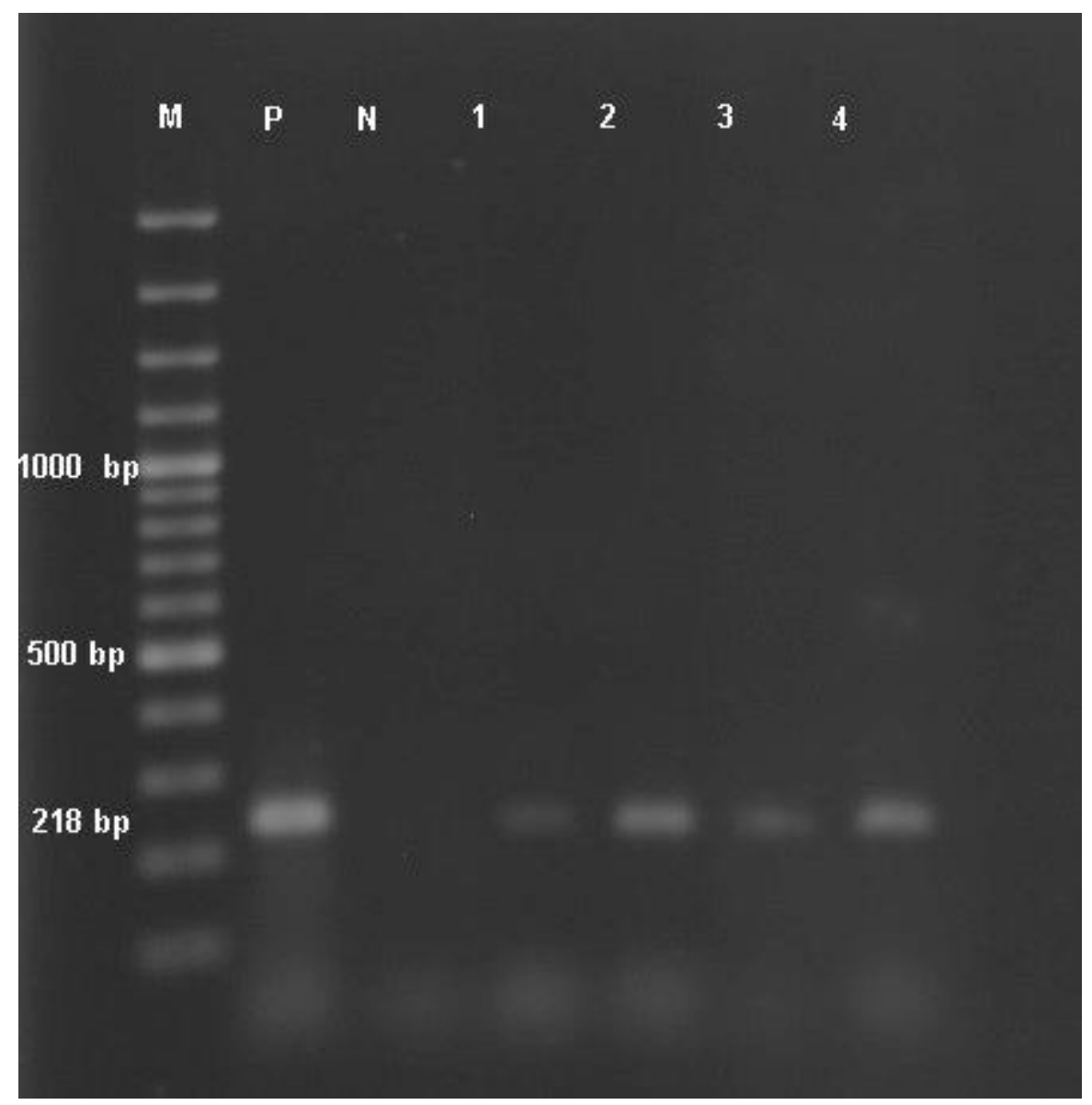

Figure 3. Electrophoresis results of SSUrRNA gene with special primers, M: Marker, P: Positive control, N: Negative Control, 1, 2, 3 and 4: Nosema Positive samples (218bp) 


\section{ARAŞTIRMA MAKALESI / RESEARCH ARTICLE}

Table 1. Comparison of detection Nosema spp. infection in apiaries by Microscopy and PCR

\begin{tabular}{l|c|c|c}
\hline Variable & \multicolumn{2}{|c|}{ PCR } & Total \\
\hline \multicolumn{1}{c|}{ The size of apiary } & $\begin{array}{c}\text { Negative } \\
\mathrm{N}\end{array}$ & $\begin{array}{c}\text { Positive } \\
\mathrm{N}\end{array}$ & \\
\hline $10-100$ hives & 4 & $18(81.8)$ & 22 \\
\hline$>100$ hives & 1 & $9(90)$ & 10 \\
\hline Prophylaxis drug & & & \\
\hline Fumagillin use & 1 & $10(90.9)$ & 11 \\
\hline Fumagillin no use & 4 & $17(80.9)$ & 21 \\
\hline Total & 5 & $27(4.5)^{*}$ & 32 \\
\hline
\end{tabular}

Table 2. Frequency of N.ceranae infection by size of apiaries

\begin{tabular}{l|l|l}
\hline Results & Number & $(\%)$ \\
\hline Both Microscopy and PCR (+) & 23 & 71.8 \\
\hline Both Microscopy and PCR (-) & 3 & 9 \\
\hline Microscopy (+), PCR (-) & 2 & 6.2 \\
\hline Microscopy (-), PCR (+) & 4 & 12.5 \\
\hline
\end{tabular}

\section{DISCUSSION}

The frequency of Nosema spp. infection was $78.12 \%$ in apiaries in the present study based on microscopic examination. The rate of Nosema spp. infection was reported to be $50 \%-90 \%$ in Iranian apiaries in different regions by a microscopy method (Razmaraii and Karimi 2010, Moshverinia et al. 2012, Khezri et al. 2018). The frequency of Nosema spp. infection was reported to be $22.4 \%-35.4 \%$ in Germany (Gisder et al. 2010), $78.6 \%-94.6 \%$ in Balkan countries (Stevanovic et al. 2011), and $20.59 \%$ in Saudi Arabia (Ansari et al. 2017) by microscopic examination. The differences in the reported prevalence of Nosema infection may depend on the climate of each country, health management practices in apiaries, and sampling and diagnostic methods. Two studies were reported $N$. apis infection in Iranian apiaries by microscopic method (Razmaraii and Karimi 2010, Mashverinia et al. 2012). The results of these studies are questionable, because, the spores of two Nosema species are very similar and there is no morphological index for two species differentiation.

Molecular examination showed that $87.37 \%$ of the apiaries of this study were infected with $N$. ceranae only. Our results are consistent with other molecular studies that determined that $N$. ceranae was the only causative agent of nosemosis in Iranian apiaries (Nabian et al. 2011, Khezri et al. 2018, Mohhamadian et al. 2018). The high prevalence of $N$. ceranae in this study may be related to subtropical climate in the areas. The proportion of $N$. ceranae infections appears to dominate in warmer climates compared to more temperate regions, whereas $N$. apis presently may be more prevalent in colder climates (Fries 2010).

The results of many studies have shown that $N$. ceranae infection has a worldwide distribution (Klee et al. 2007). The prevalence of $N$. ceranae was $15 \%$ $100 \%$ in Turkey (Ivgin Tunca et al. 2016), 63\% in Italy (Papini et al. 2017), $80.6 \%$ in Poland (Michalczyk et al. 2011), 95\%-97\% in Hungary (Csáki et al. 2015), 77\% in Bulgaria (Shumkova et al. 2018), 41\%-91\% in Canada (Emsen et al. 2016), and $56 \%$ in Saudi Arabia (Ansari et al. 2017).

In the present study, a fair agreement was observed between microscopy and PCR results, while other studies have reported substantial to good agreement between the two methods (Khezri et al. 2018, Papini et al. 2017). It is clear that the sensitivity and specificity of PCR method is higher than light microscopy for identification and differentiation of Nosema infection in honeybees (Michalczyk et al. 2011). However, the PCR results were negative in two samples, even though the spores were observed. The results may be related to incomplete DNA extraction or the prevention effect of the resilient walls on DNA extraction (Webster et al. 2004). The isolated $N$. ceranae sequences in this study had high-level homology with $N$. ceranae sequences of $N$. ceranae collected in China that were deposited in the GenBank database. The Fumagillin as an antibiotic extracted from Aspergillus fumagitus has been used for treatment of nosemosis in apiaries for several years. Recent studies have been shown that fumagillin is a carcinogenic substance and its residue in honey is dangerous for human health. (Van den Heever et al. 2014). For this reason, European countries have banned its use in apiary. Nevertheless, it is still used as a drug for nosomiasis treatment in Iran (Moradi, 2019) and other countries (McCallum et al. 2020; Glavinic et al. 2021). We also investigated the effectiveness of preventive fumagillin treatment in this study. The results showed that the level of Nosema spp. infection did not differ between treated and untreated colonies. An experimental study showed that $N$. ceranae is not very sensitive to low doses of fumagillin, and it can actually cause hyperproliferation of Nosema spp. in infected honeybees. (Williams et al. 2010). Our findings showed that $N$. ceranae at a high frequency are the only causative agent of nosemosis in Mazandaran 


\section{ARAŞTIRMA MAKALESI / RESEARCH ARTICLE}

province. Furthermore, the use of fumagillin was not adequate for controlling nosemosis in infected colonies.

Ethics statement: Study protocols and methodologies were revised and approved by the Ethical Committee at Ferdowsi University of Mashhad, Khorasan Razvi Province, Iran

Grant support: This study was supported by the grant VPRTFM- 3/43533 from the Vice President Research and Technology of Ferdowsi University of Mashhad, Iran.

Conflict of interest: The authors declare that they have no conflict of interest.

Author contributions: A.S collected samples and performed all experiments. G.R.R was the supervisor of project and analyzed the data and was a major contributor in writing the manuscript. All authors read and approved the final manuscript.

\section{Acknowledgments}

We are very grateful to $\mathrm{H}$. Eshrati for his technical assistance.

\section{REFERENCES}

Ansari, MJ., Al-Ghamdi, A., Nuru, A., Khan, KA., Alattal, Y. 2017. Geographical distribution and molecular detection of Nosema ceranae from indigenous honey bees of Saudi Arabia. Saudi $J$ Biol Sci. 24(5):983-991. DOI: 10.1016/j.sjbs.2017.01.054.

Bailey, L., Ball, BV. 1981. Honey Bee Pathology. Academic Press, London.

Csáki, T., Heltai, M., Markolt, F., Kovács, B., Békési, L., Ladányi, M., Péntek-Zakar, E., Meana, A., Botías, C., Martín-Hernández, R., Higes, M. 2015. Permanent prevalence of Nosema ceranae in honey bees (Apis mellifera) in Hungary. Acta. Vet. Hung. 63(3):358-69. DOI: 10.1556/004.2015.034.

Emsen, B., Guzman-Novoa, E., Hamiduzzaman, MM., Eccles, L., Lacey, B., Ruiz-Pérez, RA., Nasr, M. 2016. Higher prevalence and levels of Nosema ceranae than Nosema apis infections in Canadian honey bee colonies. Parasitol Res 115(1):175-81. DOI: 10.1007/s00436-015-4733-3.

Fenoy, S., Rueda, C., Higes, M., Martín-Hernández, R., del Aguila, C. 2009. High-level resistance of Nosema ceranae, a parasite of the honeybee, to temperature and desiccation.
Appl. Environ. Microbiol. 75(21):6886-6889. doi:10.1128/AEM.01025-0918.

Fries, I. 2010. Nosema ceranae in European honey bees (Apis mellifera) J. Invertebr. Pathol. 103(1): 10.1016/j.jip.2009.06.017. S73-S79.DOI:

Fries, I., Feng, F., Silva, AD., Slemenda, SB., Pieniazek, NJ. 1996. Nosema ceranae n. sp. (Microspora, Nosematidae), morphological and molecular characterization of a microsporidian parasite of the Asian honey bee Apis cerana (Hymenoptera, Apidae) Europ. J. Protistol. 32(3):356-365.

Glavinic, U., Stevanovic, J., Ristanic, M., Rajkovic, M., Davitkov, D., Lakic, N., \& Stanimirovic, Z. 2021. Potential of Fumagillin and Agaricus blazei Mushroom Extract to Reduce Nosema ceranae in Honey Bees. Insects, 12(4), 282. https://doi.org/10.3390/insects12040282

Gisder, S., Hedtke, K., Möckel, N., Frielitz, MC., Linde, A., Genersch, E. 2010. Five-year cohort study of Nosema spp. in Germany: does climate shape virulence and assertiveness of Nosema ceranae? Appl. Environ. Microbiol. 76(9):3032-3038. DOI: 10.1128/AEM.03097-09.

Higes, M., Martín, R., Meana, A. 2006. Nosema ceranae, a new microsporidian parasite in honey bees in Europe. J. Invert. Pathol. 92 (2):93-95.

Ivgin Tunca, R., Oskay, D., Gosterit, A., Tekin, OK. 2016. Does Nosema ceranae wipeout Nosema apis in Turkey? Ir. J. Parasitol, 11(2): 259-264.

Kazembeyki, MA. 2003. Society, Politics and Economics in Mazandaran, Iran, Routledge Cruzon, London.

Khezri, M., Moharrami, M., Modirrousta, H., Torkaman, M., Salehi, S., Rokhzad, B., Khanbabi, H. 2018. Molecular detection of Nosema ceranae in the apiaries of Kurdistan province, Iran. Vet. Res. Forum 9(3):273-278. DOI: 10.30466/vrf.2018.32086.

Klee, J., Besana, AM., Genersch, E., Gisder. S., Nanetti, A., Tam, DQ., Chinh, TX., Puerta, F., Ruz, JM, Kryger, P., Message, D., Hatjina, F., Korpela, S., Fries, I., Paxton, RJ. 2007. Widespread dispersal of the microsporidian Nosema ceranae, an emergent pathogen of the western honey bee, Apis mellifera, J. 


\section{ARAŞTIRMA MAKALESI / RESEARCH ARTICLE}

Invertebr. Pathol. 96(1): 1-10. DOI: 10.1016/j.jip.2007.02.014.

Lotfi, A., Jamshidi, R., Aghdam Shahryar, H., Yousefkhani, M. 2009. The prevalence of nosemosis in honey bee colonies in Arasbaran region (Northwestern Iran). J. Agri Environ. Sci. 5(2): 255-257.

McCallum, R. Olmstead, S. Shaw, J. Glasgow, K. 2020. Evaluating efficacy of Fumagilin- $B \circledR$ against Nosemosis and tracking seasonal trends of Nosema spp. in Nova Scotia Honey bee colonies. J.Apic. Sci.2020.64(2):277-286.

Martín-Hernández, R., Meana, A., Prieto, L., Salvador, AM., Garrido-Bailón, E., Higes, M. 2007. Outcome of colonization of Apis mellifera by Nosema ceranae. Appl. Environ. Microbiol. 73:6331-6338. DOI: 10.1128/AEM.00270-07.

Michalczyk, M., Sokół, R., Szczerba-Turek, A., Bancerz-Kisiel, A. 2011. A comparison of the effectiveness of the microscopic method and the multiplex PCR method in identifying and discriminating the species of Nosema spp. spores in worker bees (Apis mellifera) from winter hive debris. Pol. J. Vet. Sci. 14(3):38591. DOI: 10.2478/v10181-011-0058-z.

Mohammadian, B., Bokaie, S., Moharrami, M., Nabian, S., Forsi, M. 2018. Distribution of Nosema spp. in climatic regions of Iran. Vet Res Forum. 9(3):259-263. DOI: 10.30466/vrf.2018.32082.

Moradi, M. 2019. Survey of Thymus volgaris ethanolic effects on the Nosema parasite in honeybee. Iranian. H. Sci.Tech .9 (17): 24-32.

Moshverinia, A., Abedi, V., Safaie, H. 2012. A survey of Nosema apis infection in apiaries of North Khorasan province, Iran. Ir. J Vet Sci Tech 4: 25-30. DOI: 10.22067/veterinary.v4i2.17418.

Nabian, S., Ahmadi, K., Shirazi, MN., Gerami Sadeghian, A. 2011. First detection of Nosema ceranae, a microsporidian protozoon of European honeybees (Apis mellifera) in Iran. Ir.J.Parasitol. 6: 89-95. PMID: 22347302.

OIE. 2019. Manual for diagnostic tests and vaccines for terrestrial animals, Nosemosis of honey bees, Paris.

Papini, R., Mancianti, F., Canovai, R., Cosci, F., Rocchigiani, G., Benelli, G., Canale, A. 2017. Prevalence of the microsporidian Nosema ceranae in honeybee (Apis mellifera) apiaries in Central Italy. Saudi. J. Biol. Sci. 24 (5):979982. DOI: 10.1016/j.sjbs.2017.01.010.

Petrie A., Watson P. 2006. Statistic for veterinary and animal science. Blackwell Oxford.

Razmaraii, N., Karimi, H. 2010. A survey of Nosema disease of honey bee (Apis mellifera) in East Azarbaijan province of Iran. J. Anim.Vet. Adv. 9: 879-882. DOI: 10.3923/javaa.2010.879.882.

Shumkova, R., Georgieva, A., Radoslavov, G., Sirakova, D., Dzhebir, G., Neov, B., Bouga, M., Hristov, P. 2018. The first report of the prevalence of Nosema ceranae in Bulgaria. Peer J 31;6:e4252. DOI: 10.7717/peerj.4252.

Stevanovic, J., Stanimirovic, Z., Genersch, E., Kovacevic, SR., Ljubenkovic, J., Radakovic, M., Aleksic, N. 2011. Dominance of Nosema ceranae in honey bees in the Balkan countries in the absence of symptoms of colony collapse disorder. Apidologie 42: 49-58. DOI: 10.1051/apido/2010034.

Tavassoli, M., Eiganinejad, S., Alizadeh-Asl, S. 2009. A survey on Nosema apis infection in apiaries of Urmia, North-West of Iran. Ir. J. Vet. Sci. Tech. 1(1): 35-40.

Thursfield, MV.1986. Veterinary epidemiology, Butterworth, Guilford, London.

Tokarev, YS., Huang, WF, Solter, LF., Malysh, JM., Becnel, JJ., Vossbrinck, CR. 2020. A formal redefinition of the genera Nosema and Vairimorpha (Microsporidia: Nosematidae) and reassignment of species based on molecular phylogenetics. J.Inver. Pathol. 169: 107279, doi.org/10.1016/j.jip.2019.107279.

Van den Heever, JP., Thompson, TS., Curtis, JM., Ibrahim, A., Pernal, SF.2014. Fumagillin: an overview of recent scientific advances and their significance for apiculture. J. Agric. Food. Chem. 62:2728-37. doi: 10.1021/j44055374.

Webster, TC., Pomper, KW., Gerg, H., Thacker, EM., Jones, SC. 2004. Nosema apis infection in worker and queen Apis mellifera. Apidologie. 35(1): 49-54.

Williams, GR., Shutler, D., Little, CM., Burgher-MacLellan, KL., Rogers, REL. (2010). The microsporidian Nosema ceranae, the antibiotic Fumagilin-B, and western honey bee (Apis mellifera) colony strength. Apidologie 42 (1): 15-22. 